Hovudproblemet mitt med artikkelen er at det ser ut til at svaret deira er «ja»: «Basert på vår erfaring mener vi dette er veien å gå,» skriv dei, og det ser ut til at dette peiker attende på auka utdanningsnivå, kompetanseheving og formell forskriftsfesting av ambulansenivået.

Mi meining er tvert om at eg ikkje ønsker den stasjonære legevaktlegen som distanserer seg frå akuttmedisinen, og eg vil kort grunngje det slik:

Frå min kommune, Austevoll i Hordaland, har me publisert to artiklar som beskriv alle akuttmedisinske hendingar i kommunen i toårsperioden 2005-2007 (2, 3). Av funn i studien vil eg framheve at talet på diagnoser ved dei 236 akutthendingane som legen vurderte, var 62. Med andre ord er den udifferensierte akuttmedisinen ved helsepersonellet sin første kontakt med pasienten, ein svært variert arena.

Den innskrenkar seg ikkje til eit fåtal kjernetilstandar, der intensiv trening i prosedyrer er det som er viktig. At mange akutte situasjonar er prega av diffus og raskt endrande symptomatologi, gjer at ein generelt høg medisinsk kompetanse er viktig for å gjere rette handlingar og få pasienten til rett nivå.

Eit anna funn gjeld den endring av alvorsvurdering som skjer i forløpet av ein akuttmedisinsk aksjon. I vårt materiale nedgraderte legen den initiale alvorsvurderinga ved meldingsmottaket i $42 \%$ av tilfella, då ho eller han faktisk fekk undersøkt pasienten. Med andre ord er det behov for ein høg grad av diagnostisk utelukkingskompetanse i den prehospitale akuttmedisinen.

Kanskje like viktig er det at alvorsgraderinga vart auka i $11 \%$ av tilfella. Det viktige for å kunne forstå eller gjenkjenne at ein tilstand er meir alvorleg enn ein først hadde tenkt, er å ha generelt gode medisinske kunnskapar.

Eg synest at desse enkle kjensgjerningane burde vere nok til å forstå at den medisinske profesjonen, legen, er essensiell i akuttsituasjonane.

Det finst ikkje noko datamateriale som beskriv variasjonen av utdannings- og kompetansenivå hos ambulansearbeidarar. Realiteten er nok at den høge kompetansen som mange legar skulle ønska at skulle finnast i ambulansetenesta, i mange tilfelle ikkje er der, og at det er slik desto lenger ein kjem frå dei geografiske sentra. Nesten-lege-ambulansearbeidaren vil aldri komme til å bli hyppig i utkantane.

\section{Sverre Rørtveit}

sverre.rortveit@austevoll.kommune.no

Sverre Rørtveit (f. 1949) er kommunelege 2 i Austevoll kommune og fastlege ved Bekkjarvik legekontor

Ingen oppgitte interessekonflikter.

\section{Litteratur}

1. Kindt PG, Momyr M, Sundland E et al. Prehospital akuttmedisin uten legevaktlege? Tidsskr Nor Legeforen 2013; 133: 1176-7.

2. Rørtveit S, Hunskår S. Akuttmedisinske hendingar i ein utkantkommune. Tidsskr Nor Legeforen 2009; 129: 738-42.

3. Rørtveit S, Hunskår S. Akuttmedisinsk handsaming i ein utkantkommune. Tidsskr Nor Legeforen 2009; 129: 735-7.

Dette er en redigert versjon av et innlegg publisert som rask respons på nett 23.6.2013. http://tidsskriftet.no/article/3019306/

\section{P. G. Kindt og medarbeidere svarer:}

Vi takker for interessante kommentarer fra Rørtveit og Zakariassen og beklager at vi ikke refererte til Rørtveit og Hunskårs artikler fra 2009. Vi konstaterer at vi alle er enige $i$ at dette er et viktig problemområde som fortjener økt oppmerksomhet. For oss var det vesentlig å få frem hovedpoenget, nemlig at legevaktlegen i forbausende liten grad er involvert i akutte medisinske hendelser utenfor sykehus. Vår undersøkelse var retrospektiv og derfor neppe helt presis. Kanskje er legenes reelle involvering noe høyere, slik Zakariassen antyder. Det er imidlertid neppe noen tvil om at tallet er lavt.
Vi er enige $i$ at vi trenger søkelys på selve varslingen: I hvilken grad blir legevaktlegen faktisk varslet av AMK-sentralen ved akutte hendelser slik forskriften krever? Dette hadde vi dessverre ikke undersøkt. Likeledes trenger vi mer kunnskap om hvorfor legevaktlegen velger ikke å rykke ut i situasjoner hvor han/hun er varslet. Vi tror dette henger sammen med etableringen av stadig større flerkommunale legevaktdistrikter, noe som gjør det svært problematisk for legen å rykke ut. I flere distrikter er det 10-15 mil mellom distriktets utkanter.

Rørtveit er bekymret fordi vi tar til orde for at veien videre er en ytterligere styrking av ambulansepersonellets utdanning og kompetanse. Vi deler hans bekymring. Han har utvilsomt rett $i$ at den primære kontakten er en svært krevende arena, med varierte og vanskelige problemstillinger, noe som krever høy kompetanse. Han har også rett i at det er vanskelig å gjøre korrekte alvorlighetsvurderinger. Når vi skriver som vi gjør, er det ikke fordi vi ønsker at legen skal være lite involvert, men fordi vi har en sterk følelse av at den utviklingen vi beskriver, har kommet for å bli: Legen blir mer stasjonær og overlater stadig mer av det primære arbeidet inkludert diagnostikk og behandling - til ambulansepersonellet.

Det gleder oss at debatten er i gang og at både Rørtveit og Zakariassen synes å ønske at legevaktlegen skal være mer aktiv. I så fall kreves en kraftig bevisstgjøring og økt søkelys fra legenes side, inkludert en styrket akuttmedisinsk utdanning, og antagelig også organisatoriske grep.

Kan det tenkes at også bekvemmelighetshensyn fra legenes side spiller en rolle?

\section{Petter G. Kindt \\ petter.kindt@gmail.com \\ Marius Momyr \\ Erlend Sundland \\ Sven Erik Gisvold}

Petter G. Kindt (f. 1988) er turnuslege ved Sykehuset Innlandet, Divisjon Elverum-Hamar og har arbeidserfaring fra akuttmottaket ved St. Olavs hospital og ambulansetjenesten i Trondheim.

Ingen oppgitte interessekonflikter.

Marius Momyr (f. 1983) er turnuslege ved Orkdal Sjukehus og har arbeidserfaring fra allmennpraksis ved Saupstad legesenter og ambulansetjenesten i Trondheim.

Ingen oppgitte interessekonflikter.

Erlend Sundland (f. 1954) er utdannet anestesisykepleier og jobber nå som avdelingssjef for Sør-Trøndelag i Ambulanse Midt-Norge. Ingen oppgitte interessekonflikter.

Sven Erik Gisvold (f. 1944) er professor dr.med. ved Institutt for sirkulasjon og bildediagnostikk, Norges teknisk-naturvitenskapelige universitet og overlege ved Anestesiavdelingen, St. Olavs hospital.

Ingen oppgitte interessekonflikter.

\section{Kan høyt kolesterol være gunstig?}

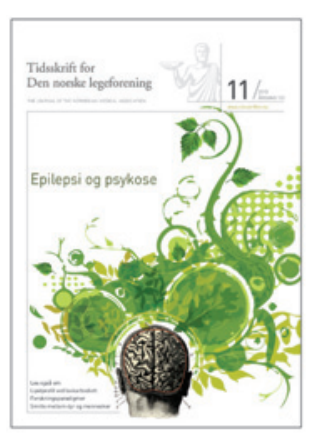

I en artikkel i Tidsskriftet nr. 11/2013 fremstilles den lipidprofilen som oppsto etter et forsøk med lavkarbokosthold, som noe som ensidig økte risikoen for å få hjerte- og karsykdom (1). Jeg er usikker på om det er grunnlag for å være så bastant. Det finnes nemlig også forandringer i lipidprofilen som er positive, og som kanskje kan oppveie de eventuelt negative forandringene i lipidmønsteret. Deltakerne i studien fikk nemlig en betydelig økning i HDL-nivået, noe mange eksperter på området vil tolke som helsemessig gunstig. 
Det er også grunn til å minne om at ikke alle vitenskapelige studier viser at et høyt kolesterolnivå nødvendigvis er negativt for hjertet. I Tidsskriftet nr. 12/2012 presenteres det en fersk studie fra det medisinske miljøet ved Norges teknisk-naturvitenskapelige universitet, hvor det viser seg at for kvinner er det et inverst forhold mellom totalkolesterolverdien og forekomsten av kardiovaskulær dødelighet (2). Jo høyere totalkolesterol kvinnene hadde, desto lavere var den kardiovaskulære dødeligheten.

Det finnes etter hvert mange studier som går i en slik retning - for eksempel 30 års-oppfølgingsstudien etter den store og berømte Framingham-studien (3). Her fremkommer det: «There is a direct association between falling cholesterol levels over the first 14 years and mortality over the following 18 years (11\% overall and $14 \%$ CVD death rate increase per $1 \mathrm{mg} / \mathrm{dL}$ per year drop in cholesterol levels)»».

Andre vitenskapelige arbeider viser at totalkolesterolverdien i gjennomsnitt er betydelig lavere hos dem som får hjerteinfarkt enn hos friske personer på samme alder (4). Al-Mallah og medarbeidere fant også at pasienter som hadde pådratt seg hjerteinfarkt generelt hadde lavere LDL-nivå enn normalt (5). Dette viser at det er forskningsmessig belegg for å hevde at de vitenskapelige data innen dette fagområdet er sprikende, og man kan derfor heller ikke utelukke at den endringen som oppsto i lipidprofilen til kvinnene i denne studien, på sikt kan vise seg å være helsemessig gunstig.

\section{Jan Helge Halleraker}

janhelgehalleraker@yahoo.com

Jan Helge Halleraker (f. 1955) er lege og førstelektor ved Høgskolen Stord/Haugesund.

Ingen oppgitte interessekonflikter.

\section{Litteratur}

1. Baumann M, Espeland MZ, Kværner AS et al. Lipidprofil ved lavkarbokosthold hos friske. Tidsskr Nor Legeforen 2013; 133: 1193-6.

2. Viste K. Retningslinjer for kardiovaskulær risikovurdering. Tidsskr Nor Legeforen 2012; 132: 1438.

3. Anderson KM, Castelli WP, Levy D. Cholesterol and mortality. 30 years of followup from the Framingham study. JAMA 1987; 257: 2176-80.

4. Sachdeva A, Cannon CP, Deedwania PC et al. Lipid levels in patients hospitalized with coronary artery disease: an analysis of 136,905 hospitalizations in Get With The Guidelines. Am Heart J 2009; 157: 111-7, e2.

5. Al-Mallah MH, Hatahet $\mathrm{H}$, Cavalcante JL et al. Low admission LDL-cholesterol s associated with increased 3-year all-cause mortality in patients with non ST segment elevation myocardial infarction. Cardiol J 2009; 16: 227-33..

Dette er en redigert versjon av et innlegg publisert som rask respons på nett 13.6.2013. http://tidsskriftet.no/article/3019897/

\section{Totalkolesterol og kroppsfett}

I Tidsskriftet nr. 11/2013 var det en artikkel om lavkarbokosthold og lipidprofil (1). Vil man ikke under subkaloriske dietter, som nødvendigvis medfører forbrenning av kroppsfett, få en økning i serumlipider? Jeg ser sågar for meg at rene utsultingsforsøk hos personer med tilstrekkelig kroppsfett vil gi en skarp økning i serumkolesterol.

\section{Eivind Ånestad}

eivind.anestad@gmail.com

Eivind Ånestad (f. 1982) er cand.med. i turnuskø.

Ingen oppgitte interessekonflikter.

\footnotetext{
Litteratur

1. Baumann M, Espeland MZ, Kværner AS et al. Lipidprofil ved lavkarbokosthold hos friske. Tidsskr Nor Legeforen 2013; 133: 1193-6.
}

Dette er en redigert versjon av et innlegg publisert osm rask respons på nett 20.7.2013. http://tidsskriftet.no/article/3019897/

\section{Baumann og medarbeidere svarer:}

I vår studie fant vi en kraftig kolesteroløkende effekt av lavkarbohydratkosthold. Fire uker med et kosthold som besto av median 71 energiprosent fett, 26 energiprosent protein og 3 energiprosent karbohydrat medførte en økning i totalkolesterol på $33 \%$, LDLkolesterol på $41 \%$ og HDL-kolesterol på $31 \%$. Halleraker stiller spørsmål ved om disse endringene i lipidprofil kan være gunstige, ettersom høyt HDL-kolesterol er assosiert med lav hjerte- og karrisiko. De senere årene er det utviklet flere HDL-kolesteroløkende medikamenter, men resultatene fra store kliniske endepunktstudier har vært skuffende. Farmakologisk økning i HDL-kolesterol har ikke gitt reduksjon i risiko for hjerte- og karsykdom, og genetisk betinget høyt HDL-kolesterol er ikke vist knyttet til hjerte- og karrisiko (1). Dette har sannsynligvis sammenheng med at HDL-partikkelens effektivitet i den reverse kolesteroltransporten ikke er så nært knyttet til plasmakonsentrasjonen av HDL-kolesterol som man tidligere har trodd.

Det som imidlertid er godt dokumentert, er at LDL- og totalkolesterol er direkte assosiert med hjerte- og karrisiko. Forfatterne av oppfølgingsstudien som Halleraker sikter til (2), konkluderer med følgende: «After age 50 years the association of mortality with cholesterol values is confounded by people whose cholesterol levels are falling - perhaps due to diseases predisposing to death.» Funnet Helleraker henviser til, må altså tolkes med forsiktighet. En nyere norsk studie viser at en økning på $1 \mathrm{mmol} / \mathrm{l}$ i totalkolesterol er forbundet med en økning i koronardødelighet på hele $65 \%$ (3). Risikoen ved den observerte økningen i total- og LDL-kolesterol i vårt forsøk er således betydelig.

I Norge, som i våre naboland Sverige og Finland, har vi de siste 40 årene sett en reduksjon i hjerte- og kardødelighet på over $70 \%$ i aldersgruppen 40-65 år, som i betydelig grad er blitt forklart ved nedgangen i totalkolesterol (4). Engrostall viser at forbruket av mettet fett har økt i Norge de siste årene, samtidig som en fersk studie som omfatter alle sykehusinnleggelser for hjerteinfarkt for personer $\geq 25$ år i perioden 1994-2009 i Norge, viser en økning i sykehusinnleggelser for akutt hjerteinfarkt på $11 \%$ hos personer under 45 år fra 2001 til 2009 (5). Dette er alarmerende og må tas på alvor.

\section{Monica Baumann \\ monica.baumann@gmail.com \\ Martine Zakariassen Espeland \\ Ane Sørlie Kværner \\ Martin Prøven Bogsrud \\ Kjetil Retterstøl}

Monica Baumann (f. 1984) er medisinstudent og har en bachelorgrad i ernæringsvitenskap.

Ingen oppgitte interessekonflikter.

Martine Zakariassen Espeland (f. 1987) er klinisk ernæringsfysiolog ved Lovisenberg sykehus, Enhet for klinisk ernæring.

Ingen oppgitte interessekonflikter.

Ane Sørlie Kværner (f. 1989) er klinisk ernærinsfysiolog ved Avdeling for kreftbehandling, Oslo universitetssykehus.

Ingen oppgitte interessekonflikter.

Martin Prøven Bogsrud (f. 1981) er lege i spesialisering (D-stilling) $\mathrm{i}$ indremedisin. Han arbeider også med doktorgrad om bivirkninger ved statinbehandling.

Ingen oppgitte interessekonflikter.

Kjetil Retterstøl (f. 1962) dr.med. og spesialist i medisinsk biokjemi. Han har hovedstilling som førsteamanuensis ved Avdeling for ernæringsvitenskap og bistilling som overlege ved Lipidklinikken.

Oppgitte interessekonflikter: Han har mottatt forskningsmidler fra Throne Holst Stiftelse, honorar for arbeid med vitenskapelige råd for Mills DA og for foredag for Nutricia. 